\section{Reversal of the Norm: Pressure Discrepancies on the Two Sides of the Septum in Chronic Kidney Disease Patients with Congestive Heart Failure}

\author{
Awad Magbri*, \\ Shauket Rashid and \\ Brar Ballhinder
}

Dialysis Access Center of Pittsburgh, PA, USA

Received: January 04, 2018; Accepted: January 09, 2018; Published: January 13, 2018

\section{*Corresponding author: Awad Magbri}

elmagbri@hotmail.com

Keywords: Hemofiltration; Hemodialysis; Congestive heart failure; Ultra-filtration; Fluid overload; Intre-atrial septostomy

\section{Introduction}

Normally the right side of the heart is low pressure chambers that accommodate large volume of blood. On the other hand, the left side of the heart is high pressure chambers that forces blood into the major vessels to distribute it to the vital organs and the rest of the body.

Our patient is 67-year-old Caucasian male with end-stage renal disease on hemodialysis (HD) via a tunneled dialysis catheter in the right internal jugular vein for the last 8 months. He has multiple chronic comorbidities including morbid obesity with body mass index of $56.21 \mathrm{~kg} / \mathrm{m}^{2}$. Chronic lymphedema of the lower extremities, paroxysmal atrial fibrillation, obstructive sleep apnea with pulmonary hypertension on bi-level positive pressure ventilation (BIPAP). He has chronic congestive heart failure and he is on HD 3-times per week. He has no diabetes but suffered from fluid overload and inability of getting fluid off on HD sessions. He also has pressure sores from immobility. His blood pressure is chronically low 81-90/67-74 mmHg before dialysis.

This scenario is quite familiar to the nephrologists who care for dialysis patients. The treatment of such patients is difficult, and the mortality is high. Chronic kidney disease (CKD) is very common in congestive heart failure patients. As a matter of fact, patients with CKD die from cardiovascular disease long before they reach dialysis. Many workers have found that both systolic and diastolic blood pressure were inversely associated with mortality [1-7]. This phenomenon of low blood pressure with increased mortality is called "reverse epidemiology" $[3,8]$. It is not clear that any intervention will prove to be effective to curb the high mortality and morbidity of hemodialysis patients with congestive heart failure and low blood pressure.

The pathophysiology of CKD in cardiac disease is complex and involves both congestive and ischemic nephropathy and both. These patients usually have evidence of congestion with precapillary wedge pressure (PCWP) that reflects the end-diastolic pressure of the left side of the heart of $<18 \mathrm{mmHg}$. At the same time, they have low cardiac index of $<2.1 \mathrm{~L} / \mathrm{m}^{2}$ with evidence of low cardiac output and cold extremities.
MD, FACP, Dialysis Access Center of Pittsburgh, PA, USA.

Tel: 4122715106

Citation: Magbri A, Rashid S, Balhinder B (2018) Reversal of the Norm: Pressure Discrepancies on the Two Sides of the Septum in Chronic Kidney Disease Patients with Congestive Heart Failure. Acta Psychopathol Vol.4 No.1:2

The presence of both ischemic and congestive symptoms in the same patient proved to be a difficult task to manage by HD. It should be noted that chronic hypotension decreases the preload and will eventually leads to vasoconstriction and ischemia to the kidney [9-11]. Constriction of the glomerular efferent arterioles due to angiotensin-II blockade from the drugs used for the treatment of heart failure as well as activation of the tubule-glomerular feedback and tubular dysfunction with sustained decrease in intra-glomerular pressure leads to ischemic nephropathy [12].

It is not unusual to find both signs of ischemic nephropathy from chronic hypotension and congestive organomegaly with peripheral edema in the same subject, as is seen in the patient under discussion. These patients often have fluid overload and low blood pressure which makes fluid removal on dialysis extremely problematic if not almost impossible. Different maneuvers have been used to overcome these hurdles including sodium modelling, use of midodrine, decreasing ultra-filtration at the end of dialysis, putting the patients in Trendelenburg position, and lowing the temperature of the dialysate. None of these maneuvers have proven effective in end-stage renal failure patients on dialysis with concomitant congestive heart failure.

Daily slow ultra-filtration was suggested by some workers [13] to overcome this problem but are not favored by most 
patients, because tying up to hemodialysis machine for 6 or 8 hours daily is grueling undertaking for many patients. Even though, ultrafiltration and hemofiltration are fairly well tolerated hemodynamically [14,15]. Gradual and gentle removal of fluid excess is associated with symptomatic improvement and appears to improve cardiac performance. Hence improving tissue perfusion in situations of low cardiac output and fluid overload [16-19]. However, ultrafiltration has been tried on short-term basis in hospitals for patients with fluid overload and refractory congestive heart failure. It has not been translated into practical procedure in chronic hemodialysis situation because of the complexity and logistics that come with the procedure.

One wonders what we would found if we measured the pressure in

\section{References}

1 Kovesdy CP, Trivedi BK, Kalantar-Zadeh K, Anderson J (2006) Association of low blood pressure with increased mortality in patients with moderate to severe chronic kidney disease. Nephrol Dial Transplant 21: 1257-1262.

2 Duranti E, Imperiali P, sasdelli M (1996) Is hypertension a mortality risk factor in dialysis? Kidney Int Suppl 55: S173-S174.

3 Fleischmann EH, Bower JD, Salahudeen AK (2001) Risk factor paradox in hemodialysis: better nutrition as a partial explanation. ASAIO J 47: 74-81.

4 Iseki K, Miyasato F, Tokuyama K, Nishime K, Uehara H, et al. (1997) Low diastolic blood pressure, hypoalbuminemia, and risk of death in a cohort of chronic hemodialysis patients. Kidney Int 51: 1212-1217.

5 Klassen PS, Lowrie EG, Reddan DN, DeLong ER, Coladonato JA, et al. (2002) Association between pulse pressure and mortality in patients undergoing maintenance hemodialysis. JAMA 287: 1548-1555.

6 Port FK, Hulbert-Shearon TE, Wolfe RA, Bloembergen WE, Golper TA, et al. (1999) Predialysis blood pressure and mortality risk in a national sample of maintenance hemodialysis patients. Am J Kidney Dis 33: 507- 517.

7 Zager PG, Nikolic J, Brown RH, Campbell MA, Hunt WC, et al. (1998) " $U$ " curve association of blood pressure and mortality in hemodialysis patients. Medical directors of Dialysis Clinic, Inc. Kidney Int 54: 561-569.

8 Coresh J, Longenecker JC, Miller ER, Young HJ, Klag MJ (1998) Epidemiology of cardiovascular risk factors in chronic renal disease. $J$ Am Soc Nephrol 9: S24-S30.

9 MacFadyen RJ, Ng Kam Chuen MJ, Davis RC (2010) Loop diuretic therapy in left ventricular systolic dysfunction: has familiarity bred contempt for a critical but potentially nephrotoxic cardio renal therapy? Eur J Heart Fail 12: 649-652.

10 Butler J, Forman DE, Abraham WT, Gottlieb SS, Loh E, et al. (2004) the left and right ventricles in these patients. Reversal of pressure on the two sides of the interventricular septum would surprise many of us. If my intuitions of pressure reversal are proved to be true, one wonder if intre-atrial septostomy would help reverse this phenomenon and makes HD in these patients more suitable. Inter-atrial septostomy not only would increase the preload of the left side of the heart and thereby improve the blood pressure making removal of fluid easy to manage, but also relieve the congestion on the right side of the heart and the back pressure exerted on the vital organs, like the liver and the kidneys. Thereby overturning pressure difference on the two sides of the heart back to normal. Time only will tell if such procedure is going to be justified to be carried out in these patients with high mortality.

Relationship between heart failure treatment and development of worsening renal function among hospitalized patients. Am Heart $J$ 147: 331-338.

11 Knight EL, Glynn RJ, Mclntyre KM, Mogun H, Avorn J (1999) Predictors of decreased renal function in patients with heart failure during angiotensin-converting enzyme inhibitor therapy: results from the studies of left ventricular dysfunction (SOLVD). Am Heart J 138: 849-855.

12 Kazory A, Ross EA (2008) Contemporary trends in the pharmacological and extra-corporeal management of heart failure: a nephrologic perspective. Circulation 117: 975-983.

13 Canaud B, Leblanc M, Leray-Moragues H, Delmas S, Klouche K, et al. (1998) Slow continuous and daily ultrafiltration for refractory congestive heart failure. Nephrol Dial Transplant 13: 51-55.

14 Baldamus CA (1986) Hemofiltration. Hemodynamics in Hemofiltration (Edited by Henderson LW, Quellhorst EA, Lysaght MJ) Springer-Verlag, Berlin; pp: 156-200.

15 Quellhorst EA (1996) Ultrafiltration/hemofiltration practice. Replacement of renal function by dialysis (In: Jacobs C, Kjellstrand CM, Koch KM, Winchester JF Edn), Kluwer Academic Publishers, Dordrecht: 380-389.

16 Canaud B, Cristol JP, Klouche K, Béraud JJ, Du Cailar G, et al. (1991) Slow continuous ultrafiltration: a means of unmasking myocardial functional reserve in end-stage cardiac disease. Contrib Nephrol 93: 79-85.

17 Simpson LA, Rae AP, Simpson K, Gribben J, Boulton Jones JM, et al. (1986) Ultrafiltration in the management of refractory congestive heart failure. Br Heart J 55: 344-347.

18 Rimondini A, Cipolla CM, Della Bella P, Grazi S, Sisillo E, et al. (1987) Hemofiltration as short-term treatment for refractory congestive heart failure. Am J Med 83: 43-48.

19 Coraim FI, Wolner E (1995) Continuous hemofiltration for the failing heart. New Horizons 3: 725-731. 